\title{
Analisis Hambatan Belajar Mahasiswa Pada Mata Kuliah Program Linear
}

\author{
Indah Puspitasari ${ }^{1}$, Ratni Purwasih ${ }^{2}$, Adi Nurjaman ${ }^{3}$ \\ ${ }^{1,2,3}$ Program Studi Pendidikan Matematika, STKIP Siliwangi Bandung \\ Email: cviva.aulia@gmail.com
}

\begin{abstract}
Abstrak
Penelitian ini bertujuan untuk mengetahui hambatan mahasiswa dalam belajar mata kuliah program linear. analisis untuk mengetahui kesalahan mahasiswa dalam menyelesaikan soal metode simplek. Analisis kesalahan ini mengacu pada jenis-jenis kesalahan yang dikemukakan oleh peneliti Metode penelitian ini adalah deskritif kualitatif. Tempat penelitian dilaksanakan di STKIP Siliwangi, semester genap tahun 2016-2017. Penelitian ini dilaksanakan secara bertahap pada bulan FebruariMei 2017. Penelitian ini tergolong dalam penelitian deskriptif kualitatif yang berupaya untuk mendeskripsikan analisis hambatan belajar mahasiswa. Populasi penelitian adalah seluruh mahasiswa pendidikan matematika STKIP Siliwangi yang mengikuti mata kuliah program linear. Subjek penelitian adalah mahasiswa kelas B3 BP/CR yang mengikuti mata kuliah program linear pada semester genap Tahun Ajaran 2016/2017. Untuk memperoleh data penelitian digunakan instrumen berupa tes diagnostik dan wawancara. Hasil penelitian didapat kesimpulan: (1) tingkat kemampuan mahasiswa awal pembelajaran masih level rendah; (2) kesalahan mahasiswa pada umunya belum memahami soal dan prakonsep masih rendah; (3) mahasiswa belum tertanam rasa belajar secara mandiri. Adapun solusi untuk mengatasi hambatan tersebut melalui latihan atai drill soal secara terstruktur dan memberikan soal yang beragam sebagai bahan untuk berlatih. Dosen mencoba menggunakan metode yang berbeda setiap pertemuan di kelas agar mahasiswa tidak mudah jenuh dan berlatih berpikir solusi terhadap persoalan program linear.
\end{abstract}

Kata Kunci : Hambatan Belajar, Program Linear, Metode Simplek

\section{Analysis of Student Learning Barries to Linear Programming Courses}

\begin{abstract}
This study aims to determine the obstacles of students in learning courses linear courses. Analysis to know the student error in solving the problem of simplex method. Analysis of this error refers to the types of errors put forward by researchers This research method is descriptive qualitative. The place of study was conducted in STKIP Siliwangi, even semester of 2016-2017. This research was conducted gradually in February - May 2017. This research is categorized as qualitative descriptive research which attempt to describe student learning barrier analysis. The research population is all students of mathematics education of STKIP Siliwangi who follow linear course program. The subjects of the study were B3 BP / CR grade students who followed the courseof linear program in the even semester of the academic year 2016/2017. To obtain research data used instruments such as diagnostic tests and interviews. The results of the study concluded: (1) the level of early learning ability of students is still low level; (2) students' mistakes in general have not understood the problems and preconceptions are still low; (3) students have not embedded the sense of learning independently. The solution to overcome these obstacles through training or drill problems in a structured and provide a variety of problems as a material to practice. Lecturers try to use different methods every classroom meeting so that students are not easily saturated and practice thinking solutions to linear programming problems.
\end{abstract}

Keywords : Barriers to Learning, Linear Program, Simplek Method. 


\section{JIPM (Jurnal Ilmiah Pendidikan Matematika), 6(1), September 2017- 40}

Indah Puspitasari, Ratni Purwasih, Adi Nurjaman

\section{PENDAHULUAN}

Pendidikan memiliki niat yang baik ikut serta berperan penting dalam ranah hidup manusia. Suatu proses penambahan ilmu dan perubahan sikap menuju ke arah lebih baik merupakan hakikat dari pendidikan. Dalam pelaksanaan pendidikan terdapat proses pembelajaran, dimana dalam setiap jenjangnya peserta didik dituntut untuk mengikuti mata kuliah tertentu, termasuk mata kuliah program linear.

Menurut Sariningsih \& Purwasih (2017) mengemukakan bahwa faktanya, pendidikan matematika mendorong masyarakat untuk selalu maju, terbukti dengan adanya perkembangan teknologi modern. Oleh karena itu, belajar matematika dengan baik merupakan langkah berpikir logika bagi setiap orang. Matematika di jenjang Perguruan Tinggi (PT) sangatlah berbeda dengan matematika pada jenjang lainnya. Karena menurut Ruseffendi (2006) bahwa matematika di perguruan tinggi mencakup 4 wawasan yang luas yaitu: aritmatika, aljabar, geometri, dan analisis. Sedangkan menurut Suherman (Wahyuni, 2017) matematika di PT terbagi ke dalam 3 bidang, yaitu: aljabar, analisis, dan geometri.

Dalam mengembangkan penguasaan konsep pelajaran yang baik, komitmen mahasiswa dibutuhkan untuk memberi arti dalam proses belajar mandiri, antara lain dengan meningkatkan keinginan untuk mencari hubungan konseptual antara pengetahuan yang dimiliki dengan yang dipelajari di dalam perkuliahan, dan dosen berperan sebagai fasilitator proses belajar mahasiswa. Akan tetapi pada beberapa perkuliahan yang sebelumnnya telah ditempuh mahasiswa pendidikan matematika khususnya jurusan pendidikan matematika di STKIP Siliwangi yang menjadi subyek penelitian ini bersama dengan peneliti, masih banyak mahasiswa yang belum bisa menjadi pembelajar mandiri.
Aktivitas pembelajaran matematika merupakan suatu proses untuk pembentukan mindsite agar tercipta pola pikir yang sistematis dari yang mudah sampai yang sukar. Namun pada kenyataanya, masih banyak mahasiswa yang belum memiliki karakter yang sesuai tujuan pembelajaran matematika itu sendiri. Salah satu karakter yang diharapkan adalah kemandirian untuk meraih prestasi belajar yang maksimal. Adapun beberapa contoh sikap yang masih belum optimal dimiliki oleh mahasiswa adalah: (1) pengumpulan tugas belum tepat waktu; (2) keterambatan masuk ruangan kuliah; (3) tidak mempersiapkan diri sebelum perkuliahan dilaksanakan; (4) pada saat dosen tidak hadir atau sakit mahasiswa masih membuang waktu untuk hal yang kurang bermanfaat.

Kesulitan belajar tidak hanya terjadi pada jenjang sekolah dasar atau menengah namun dapat terjadi pula pada orang tua. Hal ini sejalan dengan Kereh, Subandar, \& Tjiang (Wahyuni, 2017), kesulitan belajar matematika dapat terjadi pada hampir setiap tahap/ jenjang selama masa sekolah peserta didik, bahkan pada orang dewasa (mahasiswa). Beranekaragam tingkat kesulitan yang dialami peserta didik mulai dari kurang paham terhadap konsep sampai motivasi belajar yang rendah. Hal ini berpengaruh terhadap hasil belajar yang diraih dan karakter yang tertanam jauh dari target dan harapan.

Pembelajaran matematika memiliki tujuan yang mendukung peningkatan kemampuan peserta didik untuk berkembang. Mulai dari kemampuan pemahaman sampai kemampuan penalaran termuat dalam proses pembelajaran. Hal ini bertujuan agar potensi yang dimiliki peserta didik mampu meningkat dan berkembang secara optimal. Selain itu, sikap jujur, objektif, sistematis dan terbuka terhadap perkembangan ilmu pengetahuan merupakan harapan dari pembelajaran matematika. 


\section{JIPM (Jurnal Ilmiah Pendidikan Matematika), 6(1), September 2017- 41}

Indah Puspitasari, Ratni Purwasih, Adi Nurjaman

Program linear merupakan mata kuliah wajib yang ditempuh oleh mahasiswa Program Studi Pendidikan Matematika di STKIP Siliwangi, program linear mendapat porsi 2 sks pada semester 4. Mata kuliah program linear menjadi dasar mata kuliah matematika yang lainnya, terutama bidang matematika terapan. Berdasarkan hasil observasi di kelas dalam mengerjakan soal program linear banyak mahasiswa mengalami kesalahan dalam penyelesaian, serta nilai hasil pembelajarannya belum memuaskan. Oleh karena itu perlu sebuah analisis untuk mengetahui kesalahan mahasiswa dalam menyelesaikan soal metode simplek. Analisis kesalahan ini mengacu pada jenis-jenis kesalahan yang dikemukakan oleh peneliti. Sesuai dengan latar belakang di atas, hal-hal yang ingin diuraikan dalam artikel ini yaitu sebagai berikut: 1) Jenis kesalahan apa saja yang dibuat oleh mahasiswa jurusan pendidikan matematika dalam penyelesaian soal pada program linear?; 2) Apa penyebab terjadinya kesalahan dalam menyelesaikan soal program linear? Fokus penelitian ini adalah untuk melihat kesalahan apa saja yang dilakukan mahasiswa dalam proses penyelesaian matematis pada mata kuliah program linear. Manfaat dari penelitian ini adalah sebagai dasar atau acuan untuk pengajar atau dalam hal ini dosen dalam perkuliahan selanjutnya.

Brousseau (Wahyuni, 2017) mengemukakan tiga faktor yang dapat menyebabkan hambatan atau kesulitan belajar yang dialami oleh siswa pada saat proses pembelajaran diantaranya yaitu pembatasan konsep pembelajaran pada saat anak mengalami proses perkembangan (hambatan ontogeni), pembekalan konsep yang salah atau pengajaran konsep tidaksesuai denagn kesiapan belajar peserta didik (hambatan didaktis), aplikasi terbatas yang dimiliki oleh siswa (hambatan epistimologis). Pada saat orang dihadapkan pada kondisi yang berbeda, maka pengetahu- an yang dimiliki tidak mampu diaplikasikan (Suryadi, 2010).

\section{METODE}

Tempat penelitian dilaksanakan di STKIP Siliwangi, semester genap tahun 2016-2017. Penelitian ini dilaksanakan secara bertahap pada bulan Februari-Mei 2017. Penelitian ini tergolong dalam penelitian deskriptif kualitatif yang berupaya untuk mendeskripsikan analisis hambatan belajar mahasiswa. Menurut Lofland (Krisdiana, 2015), sumber data utama dalam penelitian kualitatif ialah kata-kata, tindakan, selebihnya adalah data tambahan seperti dokumen dan lain-lain. Dalam penelitian ini, sumber data yang digunakan antara lain: (1) Kata-kata dan tindakan merupakan sumber data utama. Sumber data utama ini dicatat melalui catatan lapangan dan rekaman audio. Pencatatannya melalui observasi dan wawancara dengan subyek penelitian dan informan, (2) Sumber tertulis, dibagi atas sumber buku dan majalah ilmiah, sumber dari arsip, dokumen pribadi, dan dokumen resmi. Dalam penelitian ini yang digunakan adalah tertulis dan wawancara.

Subyek dalam penelitian ini adalah mahasiswa semester 4 Program Studi Pendidikan Matematika STKIP Siliwangi, yang menempuh mata kuliah program linear dan mengalami hambatan dalam menyelesaikan soal tes diagnostik kesulitan belajar matematika. Data mengenai hambatan belajar diperoleh melalui soal tes diagnosa yang diberikan kepada mahasiswa. Instrument penelitian ini meliputi tes dan non tes.

Instrumen tes meliputi soal program linear dan instrumen non tes berbentuk pedoman wawancara. Untuk menilai apakah instrumen tes mempunyai validitas isi yang tinggi, biasanya penilaian ini dilakukan oleh para pakar (expert judgment). Menurut Budiyono (2003) bahwa supaya tes mempunyai 
validitas isi, harus diperhatikan hal-hal sebagai berikut: Dalam hal ini para pakar menilai apakah kisi-kisi yang dibuat oleh pembuat tes telah menunjukkan bahwa klasifikasi kisikisi telah mewakili kisi-kisi yang akan diukur. Langkah selanjutnya, para penilai menilai apakah masing-masing butir tes yang telah disusun cocok atau relevan dengan kisikisi yang diteskan. Metode pengumpulan data yang digunakan dalam penelitian ini meliputi: 1) tes yang digunakan untuk mengetahui letak kesalahan mahasiswa dalam menyelesaiakan soal program linear; 2) wawancara yang digunakan untuk mendapatkan data factor penyebab kesalahan.

\section{Teknik Analisis Data}

Penelitian ini menggunakan analisis data berupa deskriptif naratif dengan menggunakan model Miles dan Huberman. Miles dan Huberman (Sugiyono, 2011), yang mengemukakan bahwa aktivitas dalam analisis data kualitatif dilakukan secara interaktif dan berlangsung secara terus-menerus sampai tuntas, sehingga datanya jenuh. Ukuran kejenuhan data ditandai dengan tidak diperolehnya lagi data atau informasi baru. Analisis data kualitatif pada penelitian ini, yaitu: 1) data reduction merupakan tahap merangkum dan memfokuskan data hasil analisis penelitian serta menghilangkan data yang tidak terpola, kemudian data-data dikumpulkan dan dipilih sesuai dengan tujuan penelitian; 2) data display, data yang telah direduksi disajikan dalam bentuk uraian singkat sehingga mudah untuk dibaca dan dipahami baik secara keseluruhan maupun bagian-bagiannya; dan 3) conclusion drawing /verivication, kesimpulan diambil berdasarkan hasil analisis dari semua data yang telah diperoleh.

\section{Tahapan Penelitian}

Adapun tahap-tahapan penelitian yang dilaksankan meliputi: (1) Peneliti mengadakan tes kemampuan awal dan wawancara; (2) Peneliti (dosen) mengadakan perkuliahan program linear; (3) Peneliti (dosen) mengadakan kuis dan penugasan; (4) Peneliti (dosen) mengadakan Ujian Tengah Semester.

\section{HASIL DAN PEMBAHASAN}

Penelitian ini dilaksanakan pada mahasiswa semester 4 tahun ajaran 2016-2017 di STKIP Siliwangi. Jumlah satu kelas terdiri dari 44 mahasiswa. Peneliti melakukan tes awal (tes diagnostik) dan wawancara setiap mahasiswa yang mengontrak mata kuliah progam linear tersebut. Hasil dari tes awal dan wawancara bahwa mahasiswa mengalami kesulitan belajar mengenai perhitungan dasar dan mereka terbiasa menghitung menggunakan kalkukator yang ada di HP. Dalam waktu yang telah ditentukan untuk menyelesaikan tes awal, tidak semua soal dapat terselesaikan tepat waktu. Hambatan belajar ini perlu disolusikan agar mahasiswa memperoleh prestasi yang lebih baik. Pengamatan peneliti selama proses pembelajaran berlangsung, mahasiswa memiliki potensi yang baik dan kooperatif untuk meningkatkan kemajuan terhadap hasil belajar. Selain itu, mahasiswa pun mampu bekerjasama dan team work yang baik sessama temennya. Hasil tes kemampuan awal mata kuliah program linear adalah sebagai berikut ini:

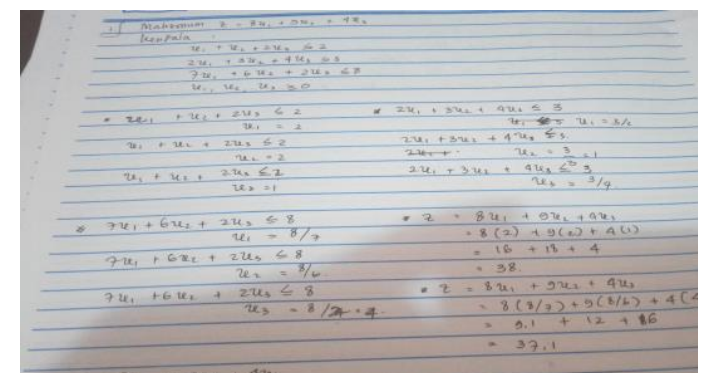

Gambar 1. Menentukan Nilai Fungsi Maksimum 


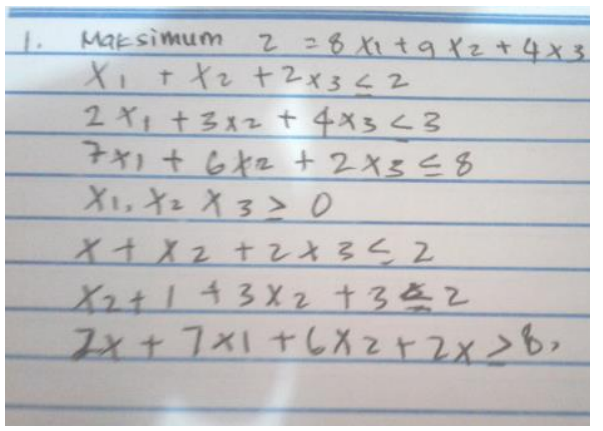

Gambar 2. Menentukan Nilai Fungsi Maksimum

Pada kedua gambar di atas menunjukan bahwa mahasiswa belum bisa menentukan nilai fungsi maksimum dari pertidaksamaan linear tiga variabel. Kesalahan yang dilakukan oleh mahasiswa pada umumnya mereka belum paham bagaimana cara menyelesaikan pertidaksamaan linear tiga variabel baik secara eliminasi, substitusi, maupun menggunakan metode simplek. Untuk metode simplek belum mereka pelajari sedangkan metode eliminasi dan substitusi sudah mereka peroleh saat bangku sekolah maupun pada saat mata kuliah sebelumnya. Tes kemampuan awal ini memberikan gambaran bahwa kemampuan awal mahasiswa belum sama. Karena masih banyak diantara mereka yang masih belum bisa menyelesaikan persoalan tersebut. Hal ini berarti mahasiswa masih memiliki hambatan dalam penguasaaan konsep mengenai materi pertidaksamaan tiga variabel atau lebih pada mata kuliah program linear.

Perhatikan gambar berikut mengenai penyelesaian system pertidaksamaan yang memiliki daerah himpunan penyelesaian seperti di bawah ini:

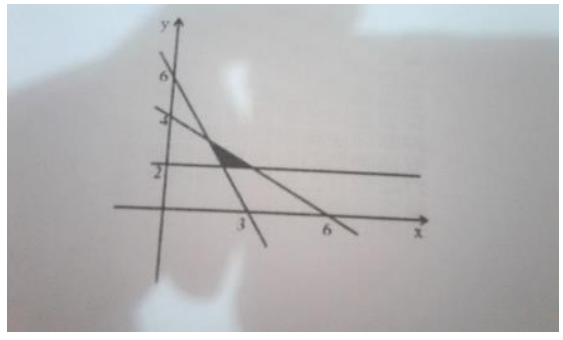

Gambar 3. Soal Sistem Pertidaksaamaan

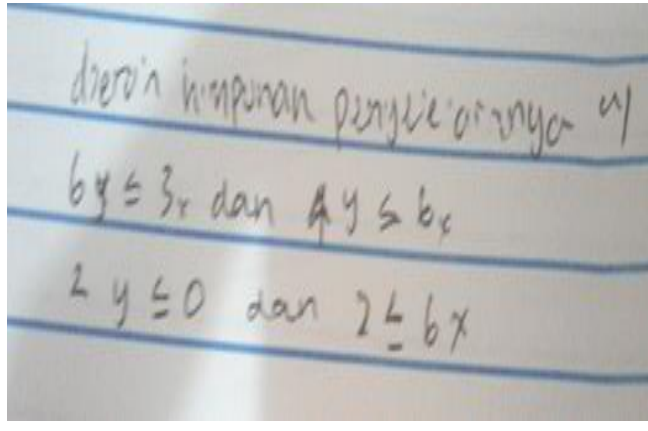

Gambar 4. Jawaban Mahasiswa

Pada Gambar 4 di atas salah satu jawaban dari mahasiswa mengenai soal sistem pertidaksamaan. Terlihat pada gambar tersebut, ide-ide dan konsep sistem pertidaksamaan belum dapat mereka kuasai secara baik.

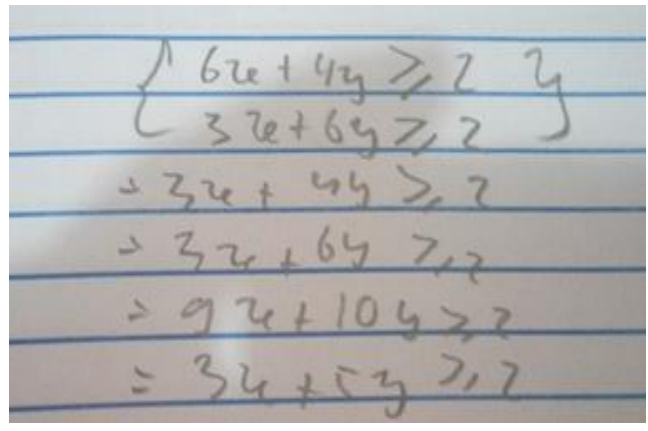

Gambar 5. Jawaban Mahasiswa

Pada materi pertidaksamaan yang memiliki daerah himpunan penyelesaian seperti pada Gambar 3 di atas, kesalahan yang dilakukan mahasiswa dalam menentukan himpunan penyelesaian dari pertidaksamaan linier tiga variabel diantaranya dikarenakan: 1) tidak hafal cara membuat persamaan garis yang melalui dua titik; 2) kesalahan perhitungan; 3) tidak paham penyelesaian pertidaksamaan.

Peneliti melakukan wawancara kepada beberapa mahasiswa yang mengontrak mata kuliah program linear ini. Adapun hasil tes wawancara mahasiswa yaitu: 1) Menurut mahasiswa pada materi nilai fungsi aljabar mengalami kesulitan dan tidak paham dalam aturan fungsi dan limit fungsi aljabar, serta mahasiswa kurang menguasai teknik berhitung; 2) Menurut mahasiswa pada materi 
nilai suatu limit mengalami kesalahan pembuktian dengan definisi limit dikarenakan lupa atau kurang teliti tentang konsep definisi limit, atau mahasiswa merasa aturan definisi limit sudah benar tetapi kesalahan menentukan pemisalan, dan mengalami kesulitan untuk menggunakan dalam soal suatu limit; 3) Menurut mahasiswa pada materi pertidaksamaan dan nilai mutlak mengalami kesalahan pengerjaan soal dikarenakan lupa atau tidak hafal sifat-sifat nilai mutlak, tidak menguasai konsep dan kurang menguasai teknik berhitung. Hal ini menunjukan tingkat kemampuan mahasiswa berbeda-beda. Peneliti melakukan beberapa pembelajaran setelah tes awal ini untuk melihat sejauhmana perubahan penguasaan terhadap materi mata kuliah program linear ini.

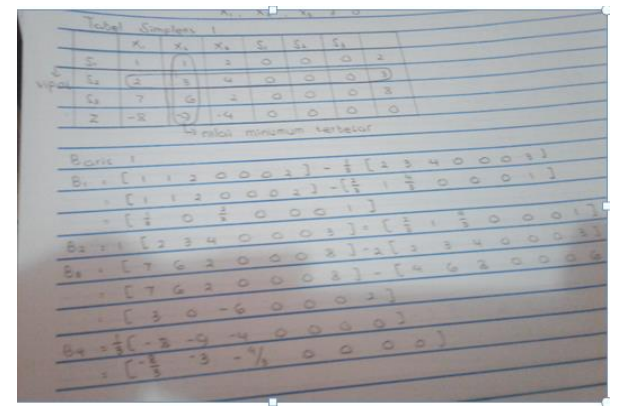

Gambar 6. Jawaban Mahasiswa Menggunakan Metode Simplek

Pada materi metode simplek untuk menentukan nilai maksimum atau minimum suatu pertidaksamaan linear, kesalahan yang dilakukan mahasiswa meliputi: 1) tidak paham membuat iterasi untuk tabel simplek; 2) tidak tepat menentukan variabel basis dan non basis; 3) tidak paham menentukan baris vipot dan kolom vipot; 4) jika masih ada nilai pada baris z (fungsi tujuan) belum negatif atau belum nol kembali ke langkah membuat iterasi tabel simpel yang baru, hal ini yang membuat mahasiswa kesulitan.

Karakteristik mahasiswa berbeda-beda, dosen harus mampu memberikan metode pengajaran yang variatif untuk mengasah berpikir dan motivasi mahasiswa pada saat di kelas. Menurut Sugilar (2017), selama ini pelaksanaan pembelajaran lebih bersifat mekanistik, mahasiswa kurang terlibat dalam proses pembelajaran, dan soal-soal latihan yang diberikan seringkali mirip dengan contoh dan bersifat rutin. Keadaan ini kurang memberi kesempatan kepada mahasiswa untuk beraktivitas dan berkreasi sesuai potensi yang dimilikinya. Hal ini membuat pola pikir mahasiswa menjadi tumpul sehingga berpengaruh terhadap prestasi belajar. Melalui tes ini, profil masing-masing mahasiswa terlihat secara jelas mana yang memiliki kecerdasan yang kreatif dan sebaliknya. Sejalan dengan penelitian Lusiana (2017) bahwa mahasiswa membaca agar menerima semua informasi yang ada pada soal, lalu memproses informasi dan menyimpannya dalam memori dalam tahap inkubasi mahasiswa dapat menentukan apa yang diketahui, ditanyakan dan yang harus dicari dari soal.

Untuk memberikan solusi terhadap mahasiswa yang belum bisa menyelesaikan persoalan metode simplek, diberikan latihan dan tugas kemudian dikoreksi agar terlihat perkembangan pemahaman mereka terhadap soal tersebut. Beberapa mahsiswa setelah diberikan treatment latihan dan tugas terstruktur mengalami perubahan yang signifikan dan mereka mampu paham apa yang sebelumnya belum jelas. Latihan terstruktur ini memberikan pengetahuan kepada mahasiswa agar terlatih dan terbiasa untuk berpikir dan solutif terhadap permasalahan program linear. Sebagaimana Krisdiana dkk. (2014) mengungkapkan bahwa segala sesuatu yang baru itu muncul dengan pemicu, di antaranya, karena tumbuh dari informasi yang baru, penemuan baru, teknologi baru, strategi belajar yang baru yang lebih variatif, sistem kolaborasi dan kompetisi yang baru, eksplorasi ke wilayah sumber informasi baru, menjela- 
jah forum komunikasi baru, mengembangkan stategi penilaian yang baru yang lebih variatif.

Temuan pertama di lapangan pada saat peneliti melakukan observasi selama pembelajaran berlangsung, pengaruh motivasi dan lingkungan teman mempengaruhi daya semangat dan keaktifan mahasiswa di kelas. Mahasiswa yang mampu menguasai konsep program linear ini mereka yang aktif bertanya dan berkelompok bersama teman yang cederung rajin belajar. Motivasi itu bisa muncul dari diri sendiri maupun dari luar (ekstrinsik). Sebagaimana penelitian dari Pramesti (2017) bahwa terdapat korespondensi yang baik antara prestasi seseorang terhadap teman sekitarnya. Ini membuktikan pengaruh teman terhadap unsur motivasi seseorang mampu memberikan dampak yang signifikan.

Temuan yang kedua, mahasiswa jarang berlatih anekaragam soal-soal yang berkaitan dengan materi kuliah yang sedang dipelajari. Untuk itu peranan dosen sangat dibutuhkan demi keseimbangan penguasaan dan pengemasan informasi yang bakal dihadapkan dan disajikan kepada mahasiswanya. Karena ada kemungkinanan mahasiswa telah memahami lebih jauh satu persoalan dari pada dosennya.

Hal ini menguatkan bahwa ternyata kemampuan akademik bukan merupakan hal yang utama dalam perkembangan pengetahuan konten, tetapi ada faktor lain misalnya

\section{DAFTAR PUSTAKA}

Budiyono, (2003). Metodologi Penelitian Pendidikan. Surakarta: Sebelas Maret University Press.

Budiyono, (2004). Statistika Untuk Penelitian. Surakarta: Sebelas Maret University Press.

Krisdiana, I., Apriandi, D., \& Setiansyah, R, K. (2014). Analisis Kesulitan Yang pengalaman, pelatihan dan motivasi intrinsik maupun ekstrinsik. Sesuai hasil penelitian dari Maryono (2016) bahwa mahasiswa yang memiliki kemampuan akademik yang baik mampu membangun pengetahuan yang lebih bermanfaat baik untuk dirinya maupun untuk sekitar.

\section{SIMPULAN}

Kesalahan-kesalahan mahasiswa dalam menyelesaikan persoalan mengenai program linear pada materi metode simplek disebabkan karena kurang memahami konsep, prakonsep dan miskonsepsi. Langkah-langkah dalam analisis hambatan dalam penelitian ini meliputi identifiaksi, klarifikasi penjelasan, koreksi, penilaian dan treatment.

Adapun kesalahan-kesalahan yang dilakukan oleh mahasiswa diantaranya: 1) mahasiswa belum paham permasalahn pada soal; 2) kecerobahan dalam proses penyelesaian masalah; 3) belum paham merubah bentuk himpunan penyelesaian pada gambar ke dalam pertidaksamaan; 4) menyelesaiakn iterasi dan tabel simplek.

\begin{abstract}
Dihadapi Oleh Guru Dan Peserta Didik Sekolah Menengah Pertama Dalam Implementasi Kurikulum 2013 Pada Mata Pelajaran Matematika (Studi Kasus Eks-Karesidenan Madiun). Jurnal Ilmiah Pendidikan Matematika (JIPM), 3(1), 1-10.
\end{abstract}

Lusiana, R. (2017). Profil Berpikir Kreatif Mahasiswa Dalam Memecahkan 
Masalah Sistem Persamaan Linier Berbasis Kontekstual ditinjau Dari Kecerdasan Matematika Logis. Jurnal Ilmiah Pendidikan Matematika, 5(2), 100-108.

Maryono. (2016). Profil Pedagogical Content Knowledge (Pck) Mahasiswa Calon Guru Matematika Ditinjau Dari Kemampuan Akademiknya. Jurnal Review Pembelajaran Matematika (JRPM), 1(1), 1-16.

Pramesti, G. (2017). Analisis korespondensi motivasi mahasiswa dalam perkuliahan. Jurnal JNPM (Jurnal Nasional Pendidikan Matematika), 1(1), 88-96.

Ruseffendi, E. T. (2006). Pengantar Kepada Membatu Guru Mengembangkan Kompetensinya dalam Pengajaran Matematika untuk Meningkatkan CBSA: Perkembangan Kompetensi Guru. Bandung: Tarsito.

Sariningsih, R.,\& Purwasih, R. (2017). Pembelajaran Based Learning untuk Meningkatkan Kemampuan Pemecahan Masalah dan Self Efficacy Mahasiswa Calon Guru. Jurnal JNPM (Jurnal Nasional Pendidikan Matematika), 4(1),163-177.
Subhan. (2009). Analisis Miskonsepsi Siswa dalam Menyelesaikan Soal Uraian Berbentuk Cerita pada Bidang Studi Matematika. Jurusan Tarbiyah STAIN Cirebon.

Sugiyono. (2011). Metode Penelitian Kuantitatif, Kualitatif dan $R \& D$. Bandung: Alfabeta.

Sugilar, H. (2017). Daya Matematis Mahasiswa Program Studi Pendidikan Matematika. Jurnal JNPM (Jurnal Nasional Pendidikan Matematika), 1(1), 97-108

Suherman, E. (2003). Evaluasi Pembelajaran Matematika. UPI Bandung: JICA.

Suryadi, D. (2010). Didactical Design Research (DDR) dalam Pengembangan Pembelajaran Matematika. Makalah pada Seminar Nasional Matematika UNNES

Wahyuni, A. (2017). Analisis Hambatan Belajar Mahasiswa Pada Mata Kuliah Kalkulus Dasar. Jurnal JNPM (Jurnal Nasional Pendidikan Matematika), 1(1), 10-21. 